\title{
Potential application of Alcaligenes faecalis strain No. 4 in mitigating ammonia emissions from dairy wastewater
}

George M. Neerackal ${ }^{a}$, Pius M. Ndegwa ${ }^{a}$, , Hung-Soo Joo ${ }^{b}$, Xiang Wang ${ }^{a}$, Craig S. Frear $^{\mathrm{a}}$, Joseph H. Harrison ${ }^{\mathrm{c}}$, Marc W. Beutel ${ }^{\mathrm{d}}$

${ }^{a}$ Department of Biological Systems Engineering, Washington State University, PO Box 646120, Pullman, WA 99164, USA.

${ }^{\mathrm{b}}$ School of Environmental Science and Engineering, Gwangju Institute of Science and Technology

(GIST), 123 Cheomdan-Gwagiro, Buk-gu, Gwangju, 500-712, Republic of Korea.

${ }^{c}$ Department of Animal Sciences, Washington State University, 2606 West Pioneer, Puyallup, WA 98371, USA.

${ }^{\mathrm{d}}$ School of Engineering, University of California Merced, 5200 North Lake Road, Merced, CA 95343, USA.

*Corresponding author. Tel.: +1 509335 8167; fax: + 15093352722.

E-mail address: ndegwa@wsu.edu (P.M. Ndegwa). 


\begin{abstract}
This research examined the potential mitigation of $\mathrm{NH}_{3}$ emissions from dairy manure via an enhanced aerobic bio-treatment with bacterium Alcaligenes faecalis strain No. 4. The studies were conducted in aerated batch reactors using air and pure oxygen. Aeration with air and oxygen removed approximately $40 \%$ and $100 \%$ total ammoniacal nitrogen (TAN), respectively. Intermittent oxygenation (every 2 or $4 \mathrm{~h}$ ) reduced oxygen consumption by 95\%, while attaining nearly identical TAN removal to continuous aeration. The results revealed that adequate oxygen supply and supplementing dairy wastewater with carbon are essential for this bioprocess. Based on the nitrogen mass balance, only $4 \%$ of TAN was released as $\mathrm{NH}_{3}$ gas, while the majority was retained in either the microbial biomass (58\%) or converted to nitrogen gas $(36 \%)$. The mass balance results reveal high potential for environmentally friendly bio-treatment of dairy wastewater using A. faecalis strain No. 4 with respect to $\mathrm{NH}_{3}$ emissions.
\end{abstract}

Keywords: Biological nitrogen removal; batch aeration; oxygenation; nitrogen gas; nitrification-denitrification 


\section{Introduction}

Biological treatments offer an attractive method for mitigating ammonia $\left(\mathrm{NH}_{3}\right)$ emissions from livestock wastewaters. Conventional nitrogen removal processes from wastewater traditionally consists of two stages: (i) aerobic autotrophic nitrification, and (ii) anaerobic heterotrophic denitrification. Nitrification transforms ammonium $\left(\mathrm{NH}_{4}^{+}\right)$to oxidized nitrogen compounds $\left(\mathrm{NH}_{4}^{+} \rightarrow \mathrm{NH}_{2} \mathrm{OH} \rightarrow \mathrm{NO}_{2}^{-} \rightarrow \mathrm{NO}_{3}^{-}\right.$); and these compounds are further reduced to nitrogen $\left(\mathrm{N}_{2}\right)$ gas via denitrification $\left(\mathrm{NO}_{3}^{-} \rightarrow \mathrm{NO}_{2}^{-} \rightarrow \mathrm{NO} \rightarrow \mathrm{N}_{2} \mathrm{O} \rightarrow \mathrm{N}_{2}\right)$ (Sun et al., 2010; Junter et al., 1995; Focht and Chang, 1975). However, biological removal of ammonium in a conventional treatment system faces several problems including: (i) an extremely slow nitrification step, (ii) strong sensitivity to oxygen limitation, (iii) negative impacts via overloading of ammonium and organic matter, and (iv) requirement of two separate reactors for nitrification (an aerobic process) and denitrification (an anaerobic

process) (Shoda and Ishikawa, 2014; Zhu et al., 2008; Joo et al., 2005). The low nitrification rates in this process result in the need for long hydraulic retention times or large reactor volumes to accomplish complete $\mathrm{NH}_{4}{ }^{+}$removal. Consequently, conventional treatment demands multiple and larger reactors and high capital and operation costs (Zhu et al., 2008; Szogi et al., 2004).

Over the past two decades, several new bio-processes for ammonium removal from municipal and domestic wastewaters have been developed, including: simultaneous nitrification and denitrification, shortcut nitrification and denitrification, anaerobic ammonium oxidation (ANAMMOX), aerobic deammonification, complete autotrophic nitrogen removal over nitrite (CANON), oxygen limited nitrification and denitrification 
(OLAND), advanced treatments using combination of theses process

(anaerobic/oxic/anoxic process, step-feed multistage anaerobic/oxic process, and membrane bioreactors), and cell-immobilization systems. These technologies possess promising features for $\mathrm{NH}_{4}{ }^{+}$removal from dairy wastewaters. However, these processes also have some potential problems or limitations similar to conventional nitrogen removal processes, such as reduced nitrification rates, longer retention times, large reactor volumes, and high operational costs which similarly limit their applications (Sun et al., 2010; Zhu et al., 2008; Junter et al., 1995).

In conventional aerobic treatment of high strength ammonia wastewaters, aeration represents the major operating cost (Ahmed et al., 2004; Water Pollution Control Federation, 1988). The use of pure oxygen gas to maintain aerobic systems has recently generated interest in wastewater treatment systems as an alternative to address the drawbacks of using air to oxygenate these systems (Palmer et al., 2009; Beutel and Horne, 1999; Brindle et al., 1998). Furthermore, use of pure oxygen to oxygenate aerobic systems has indicated potential of reducing the cost of aerating these systems (Speece, 1996). In general, systems that use pure oxygen gas rather than ambient air $\left(21 \% \mathrm{O}_{2}\right.$ by volume $)$ demonstrate better oxygen transfer efficiency, are simple and compact, allow for easier gas storage and handling, and have lower operating costs. While numerous studies have evaluated aerobic treatment system using air-based aeration methods for removing ammonia from livestock wastewaters, no studies in the literature have focused on the use of oxygenation using pure oxygen gas to drive such systems. Therefore, one component of this research study evaluated the use pure oxygen gas against ambient air to mitigate $\mathrm{NH}_{3}$ emissions from dairy wastewaters. 
In this study, it hypothesized that using a unique heterotrophic microorganism Alcaligenes faecalis strain No. 4 and aeration using pure oxygen gas would enhance the bio-treatment process to mitigate $\mathrm{NH}_{3}$ emissions from dairy wastewaters. Furthermore, it anticipated that this bio-treatment process would overcome the conventional nitrificationdenitrification drawbacks outlined previously in this paper. The bacterium A. faecalis strain No. 4 has the unique ability to consume carbon (C) and remove ammonium from wastewater mainly via nitrogen $\left(\mathrm{N}_{2}\right)$ gas and microbial assimilation in a single aerobic process (Joo et al., 2007, 2006, 2005). This is an attractive approach to biological ammonium removal from dairy wastewater because the conventional pathway of its removal via $\mathrm{N}_{2}$ can be shortened via single aerobic process $\left(\mathrm{NH}_{4}^{+} \rightarrow \mathrm{NH}_{2} \mathrm{OH} \rightarrow \mathrm{N}_{2}\right)$. Although a few studies have been conducted with $A$. faecalis under various ammonium (low and high strength) concentrations (Shoda and Ishikawa, 2014; Zhao et al., 2012; Joo et al., 2007, 2006, 2005), to date, no studies have used A. faecalis strains for treating high strength ammonium dairy-cattle manure wastewater.

The goal of this study was to search for a cost-effective bioprocess for mitigation of $\mathrm{NH}_{3}$ emissions from dairy wastewater. To achieve this goal, the following two specific objectives were formulated: (i) examine potential mitigation of $\mathrm{NH}_{3}$ emissions from highstrength-TAN dairy-cattle wastewater using A. faecalis strain No. 4, and (ii) assess the enhancement of this bioprocess using pure oxygen gas, instead of air, to maintain aerobic conditions in the system. 


\section{Materials and Methods}

\subsection{Preparation of Bacterial Culture in Shaking Culture Experiments}

The bacterium A. faecalis No. 4 was cultivated in a basal medium prepared by dissolving the following in $1 \mathrm{~L}$ lab grade water: $14 \mathrm{~g} \mathrm{~K}_{2} \mathrm{HPO}_{4}, 6 \mathrm{~g} \mathrm{KH}_{2} \mathrm{PO}_{4}, 51 \mathrm{~g}$ trisodium citrate dihydrate, $6 \mathrm{~g}$ of $\left(\mathrm{NH}_{4}\right)_{2} \mathrm{SO}_{4}, 0.2 \mathrm{~g} \mathrm{MgSO} \cdot \cdot 7 \mathrm{H}_{2} \mathrm{O}$ and $2 \mathrm{ml}$ trace mineral solution. The trace mineral contents included (per liter): $57.1 \mathrm{~g}$ EDTA·2Na, $3.9 \mathrm{~g} \mathrm{ZnSO} \cdot \cdot 7 \mathrm{H}_{2} \mathrm{O}, 7 \mathrm{~g}$ $\mathrm{CaCl}_{2} \cdot 2 \mathrm{H}_{2} \mathrm{O}, 5.1 \mathrm{~g} \mathrm{MnCl}_{2} \cdot 4 \mathrm{H}_{2} \mathrm{O}, 5.0 \mathrm{~g} \mathrm{FeSO} \cdot 7 \mathrm{H}_{2} \mathrm{O}, 1.1 \mathrm{~g}\left(\mathrm{NH}_{4}\right)_{6} \mathrm{Mo}_{7} \mathrm{O}_{24} \cdot 4 \mathrm{H}_{2} \mathrm{O}, 1.6 \mathrm{~g}$ $\mathrm{CuSO}_{4} \cdot 5 \mathrm{H}_{2} \mathrm{O}$, and $1.6 \mathrm{~g}$ of $\mathrm{CoCl}_{2} \cdot 6 \mathrm{H}_{2} \mathrm{O}(\mathrm{pH}=6.0)$. The media was autoclaved for $20 \mathrm{~min}$ at $120^{\circ} \mathrm{C}$. A $1.2 \mathrm{~mL}$ of stock solution of strain No. 4 was inoculated into a $150 \mathrm{~mL}$ of the basal medium in a $500 \mathrm{~mL}$ and cultivated at $37^{\circ} \mathrm{C}$ at the shaker agitation rate of $120 \mathrm{rpm}$ for $48 \mathrm{~h}$ prior to startup of experiments (Joo et al., 2005).

\subsection{Dairy Wastewater Collection and Preparation}

Manure samples for this study were collected from a commercial dairy farm lagoon located in central Washington, in the Pacific Northwest of the U.S.A. Samples of liquid dairy manures were transported to the lab in $20-\mathrm{L}$ sealable plastic buckets and frozen prior to use for this study. The manure samples were thawed at lab temperatures prior to startup of experiments. The dairy wastewater was screened through a $1.40 \mathrm{~mm}$ sieve to remove debris and larger solid particles. This screeing was essential to avoid pipet-tip clogging during wastewater sampling and to ensure integrity of samples. 


\subsection{Instrumentation}

The experimental set-up and instrumentation used in this study is shown in Figure 1. This system is similar to those used in similar bio-treatments of wastewaters (Shoda and Ishikawa, 2014; Zhao et al., 2010; Joo et al., 2006). Briefly, the bioreactor system consisted of a sealed Erlenmeyer flask (reactor), agitation plus temperature control system (hot plate with stirrer, catalogue no. 03407-10, Cole-Parmer Instrument Company, IL) or a shaking water bath (model 50, Thermo Scientific, $\mathrm{OH}$ ), variable area flowmeters (catalogue no. 32460-42, 5\% full-scale accuracy, Cole-Parmer Instrument Company, IL) to regulate aeration in the bioreactor system, graduated cylindrical acid traps $(250 \mathrm{~mL}$, catalogue no. 03-007-34, Fisherbrand, Mexico), and either an air compressor (model LA-5706, PUMA Industries Inc., TN) or oxygen tank to aerate the reactor.

\subsection{Aerated Batch Culture Experiments}

Two sets of aerated batch culture experiments were conducted. The first set (phase I) of experiments to test the efficacy of A. faecalis strain No. 4 in dairy wastewaters were conducted in a batch mode in which air or oxygen were introduced directly into the wastewater in $1 \mathrm{~L}$ reactors. A sample of $50 \mathrm{~mL}$ of the pre-culture (10\% inoculum) was introduced into each reactor containing $500 \mathrm{~mL}$ of dairy wastewater. The reactors were tightly sealed, stirred to ensure complete mixing of reactor contents during the process. Aeration treatments were achieved by either bubbling air or pure oxygen-gas through the reactor content. The bioreactor systems were operated for $72 \mathrm{~h}$, at $30^{\circ} \mathrm{C}$ at air or oxygen flow rates of $0.5 \mathrm{~L} \mathrm{~min}^{-1}$ and agitated at $120 \mathrm{rpm}$ with a magnetic stirrer. Samples of reactor contents were taken periodically for determination of viable cell number or microbial 
growth (at $0,16,32,48$, and $72 \mathrm{~h}$ ), and for TAN and $\mathrm{pH}$ (every $8 \mathrm{~h}$ for 72 hours). The reactor headspace gas, for each reactor, was delivered via Teflon tubing to the acid trap containing $150 \mathrm{~mL}$ of $0.2 \mathrm{M} \mathrm{H}_{2} \mathrm{SO}_{4}$ solution to capture stripped $\mathrm{NH}_{3}$ from the reactor and subsequently analyzed for TAN concentration.

In the second set, phase II, aerated batch experiments using air aeration were conducted to further examine the effects of airflow rate on TAN removal efficiency and ammonia stripping. Two sets of batch experiments were aerated using air at two different airflow rates of 0.2 and $0.5 \mathrm{~L} \mathrm{~min}^{-1}$. Each batch treatment system of the dairy wastewater was inoculated with strain No. 4 and operated at $30^{\circ} \mathrm{C}$ and an agitation speed of $115 \mathrm{rpm}$ in a reciprocal shaker. All other conditions of these experiments were similar to those of the first set of experiments.

\subsection{Reactor-Head Space Flushing Experiments}

The series of experiments described in this section were formulated to evaluate enhancement of TAN removal from dairy wastewaters using A. faecalis strain No. 4. Reactor-headspace flushing, which is the method of aeration used in this set of experiments, refers to the process of replacing headspace gases with fresh air (or oxygen gas) continuously or intermittently during the treatment time. The experiments were conducted in $500 \mathrm{~mL}$ reactors. The volume of headspace in all the reactors, therefore, was fixed at approximately $350 \mathrm{~mL}$. The bioreactor systems were operated at $30^{\circ} \mathrm{C}$ at gas flow rates of $0.1 \mathrm{~L} \mathrm{~min}^{-1}$ and at $100 \mathrm{rpm}$ in a reciprocal shaker water bath. Two sets (phases I and II) of reactor-headspace flushing experiments were conducted. 


\subsubsection{Effects of Carbon Supplementation and Oxygenation}

In the phase I studies, flushing treatments included: (i) flushing with oxygen and $\mathrm{C}$ supplementation: $150 \mathrm{~mL}$ of the dairy wastewater, $15 \mathrm{~mL}$ (10\% inoculum) of the preculture of strain No. 4 and $10 \mathrm{~g}$ trisodium citrate dehydrate were mixed in the reactor; (ii) flushing with oxygen without C-supplementation: $150 \mathrm{~mL}$ of the dairy wastewater and 15 $\mathrm{mL}$ of the pre-culture of strain No. 4 were mixed in the reactor; and (iii) flushing with air with $\mathrm{C}$ supplementation: $150 \mathrm{~mL}$ of the dairy wastewater, $15 \mathrm{~mL}$ of the pre-culture of strain No. 4 and $10 \mathrm{~g}$ trisodium citrate dehydrate $50 \mathrm{ml}$ of the pre-culture of strain No. 4 were mixed in the reactor. To compare TAN removal efficiencies in these systems, samples of reactor contents were taken periodically for determination of TAN concentrations. For oxygen-flush batch treatments of strain No. 4 using dairy wastewater supplemented with C source, concentration of hydroxylamine $\left(\mathrm{NH}_{2} \mathrm{OH}\right)$ and $\mathrm{NO}_{3}{ }^{-}$were also determined. Stripped ammonia from the reactors were measured following a similar procedure as that for the aerated batch studies in section 2.4 .

\subsubsection{Effects of Reactor Headspace-Oxygen-Flushing Durations}

In phase II studies, experiments were conducted to study the impact of different flushing durations on TAN removal efficiency. The following five flushing intervals were randomly selected for evaluation: continuous and after every $2,4,8$, and $24 \mathrm{~h}$ for about 5 min, during each flushing event. For these experiments, $150 \mathrm{~mL}$ of the dairy wastewater, 15 $\mathrm{mL}$ of the pre-culture of strain No. 4 and $10 \mathrm{~g}$ trisodium citrate dehydrate were mixed in the reactor. To monitor TAN removal, $2 \mathrm{~mL}$ samples were withdrawn from the reactor periodically throughout the process time to determine respective TAN concentrations. 


\subsection{Analytical Procedures and Methods}

The $2 \mathrm{~mL}$ samples collected periodically from respective reactors were centrifuged at $10,000 \mathrm{rpm}$ and the supernatant collected for subsequent analyses. Concentrations of TAN were determined using indophenol method adapted from standard methods (Joo et al., 2007). Hydroxylamine was analyzed following the method described in Joo et al. (2007). Nitrate was measured using Hach chromotropic acid method 10020 (Hach Company, 2004). A digital pH meter (model 290A, Orion Research Inc., MA) was used to determine the $\mathrm{pH}$. Intracellular nitrogen content $\left(\mathrm{mg}-\mathrm{N} \mathrm{L}^{-1}\right)$ was computed from biomass concentration and nitrogen content (\%) of dry cells obtained using a LECO TruSpec ${ }^{\circledR} \mathrm{CHN}$ elemental analyzer (LECO Corporation, St. Joseph, MI). Dry cells were obtained by centrifuging out mixed liquor suspended solids, which was then washed with deionized water several times prior to drying at $105^{\circ} \mathrm{C}$ for $24 \mathrm{~h}$. The contents of denitrification products (as referred to as denitrification ratio) were calculated by subtracting the concentrations of: nitrification products $\left(\mathrm{NH}_{2} \mathrm{OH}+\mathrm{NO}_{3}{ }^{-}\right)$, intracellular nitrogen, and stripped ammonium from the concentration of removed ammonium. To estimate total viable cell number (colony forming units, CFU counts) of strain No. 4, sampled culture were diluted serially and plated on LB agar plates which were incubated for $48 \mathrm{~h}$ at $37^{\circ} \mathrm{C}$. Total colonies appearing on the plates after this incubation periods were counted as A. faecalis strain No. 4 cells (Shoda and Ishikawa, 2014; Joo et al., 2005). 


\section{Results and Discussion}

\subsection{Aerated Batch Culture Experiments}

The aerated batch experiments were conducted to study viability or growth of $A$. faecalis strain No. 4 and TAN removal in dairy wastewater. Aerations were achieved by introducing either ambient air or pure oxygen gas directly into the wastewater. Figure 2 shows the changes in A. faecalis strain No. 4, wastewater $\mathrm{pH}$, TAN concentrations, and stripped $\mathrm{NH}_{3}$ during $72 \mathrm{~h}$ of treatment period when using air and oxygen for aeration.

The initial TAN levels in the wastewater in these experiments, using air and oxygen gas were similar at about $1600 \mathrm{mg}-\mathrm{N} \mathrm{L}^{-1}$ and $1500 \mathrm{mg}-\mathrm{N} \mathrm{L}^{-1}$, respectively. As shown in Fig. 3a and $3 \mathrm{~b}$, changes in TAN and stripped ammonia concentrations indicated similar trends between the two tests. The respective maximum TAN removal rates, for air and oxygen, were approximately 18.5 and $17 \mathrm{mg}-\mathrm{N} \mathrm{L}^{-1} \mathrm{~h}^{-1}$, while stripped $\mathrm{NH}_{3}$ amounted to about 843 and $807 \mathrm{mg}-\mathrm{N} \mathrm{L}^{-1}$, which accounted for approximately $50 \%$ of initial TAN. The wastewater $\mathrm{pH}$ profiles were also nearly the same for both experiments, increasing by about 0.9 and 1.3 units from the initial values for air and oxygen aerations, respectively.

The average viable cell number of $A$. faecalis strain No. 4 ranged from $1.3 \times 10^{7}$ to $5.6 \times 10^{8} \mathrm{cfu} \mathrm{mL} \mathrm{m}^{-1}$ for the aeration with air to $1 \times 10^{7}$ to $1.8 \times 10^{9} \mathrm{cfu} \mathrm{mL}^{-1}$ for aeration with pure oxygen gas, revealing growth viability of this bacterium in dairy wastewater under both aeration conditions. The viable cell number ranges of A. faecalis strain No. 4 compared well with previously reported viable cell count ranges of A. faecalis strain No. 4

cells during treatment of other types of wastewaters. In a repeated batch experiment using $A$. faecalis strain No. 4 for treatment of the municipal wastewater, Shoda and Ishikawa (2014) 
reported viable cell number of strain No. 4 cells ranging between $10^{8}$ and $10^{9}$ cells $\mathrm{mL}^{-1}$. Similarly, in a continuous experiment using strain No. 4 for treatment of the solid-free piggery wastewater, the estimated total viable cell number of $A$. faecalis strain No. 4 ranged from $1.7 \times 10^{9}$ to $8.8 \times 10^{9} \mathrm{cfu} \mathrm{mL}^{-1}$ (Joo et al., 2006).

To investigate the effects of airflow rate on TAN removal efficiency and ammonia stripping, two airflow rates $\left(0.5 \mathrm{~L} \mathrm{~min}^{-1}\right.$ and $\left.0.2 \mathrm{~L} \mathrm{~min}^{-1}\right)$ were tested using air. The initial TAN levels in the wastewater in these experiments were similar at about 1583 and $1578 \mathrm{mg}$ $\mathrm{L}^{-1}$, respectively. Figure 3 shows the changes in wastewater $\mathrm{pH}$, TAN concentrations, and stripped $\mathrm{NH}_{3}$ during $72 \mathrm{~h}$ of treatment period. When the airflow rate was held at $0.5 \mathrm{~L} \mathrm{~min}^{-1}$, approximately $1216 \mathrm{TAN} \mathrm{mg} \mathrm{L}^{-1}$ was removed, the wastewater $\mathrm{pH}$ increased from 7.7 to 9.1, and $785 \mathrm{NH}_{3} \mathrm{mg} \mathrm{L}^{-1}$ was stripped. On the other hand, when the airflow rate was held at $0.2 \mathrm{~L} \mathrm{~min}^{-1}$, approximately $799 \mathrm{TAN} \mathrm{mg} \mathrm{L}^{-1}$ was removed, the wastewater $\mathrm{pH}$ increased from 7.7 to 9.0 , and only $383 \mathrm{NH}_{3} \mathrm{mg} \mathrm{L}^{-1}$ was stripped. The respective maximum TAN removal rates, for aeration at airflow rates of 0.5 and $0.2 \mathrm{~L} \mathrm{~min}^{-1}$, were approximately 26.3 and $12.8 \mathrm{mg} \mathrm{L}^{-1} \mathrm{~h}^{-1}$. These results showed that $\mathrm{NH}_{3}$ stripping at the higher airflow rate of $0.5 \mathrm{~L} \mathrm{~min}^{-1}$ was significantly higher (almost double) than for air aeration at $0.2 \mathrm{~L} \mathrm{~min}^{-1}$. The higher $\mathrm{NH}_{3}$ stripping during the aeration experiments at higher aeration rates are in line with theory and past research studies (Ndegwa et al., 2007; Liao et al., 1995; Burton, 1992).

\subsection{Reactor-Headspace Flushing Experiments}




\subsubsection{Effects of Carbon Supplementation on TAN Removal}

This study investigated potential enhancement of this bioprocess using an external C source to supplement $\mathrm{C}$ in dairy wastewater with continuous flushing of reactor-headspace with oxygen gas. Figure 4 a shows the changes in concentrations of TAN and stripped $\mathrm{NH}_{3}$ during $24 \mathrm{~h}$ batch incubation with and without $\mathrm{C}$ addition, respectively. The process supplemented with external C resulted in nearly $100 \%$ TAN removal from an average of $1033 \mathrm{mg} \mathrm{L}^{-1}$ to $14 \mathrm{mg} \mathrm{L}^{-1}$ within $24 \mathrm{~h}$, while the wastewater $\mathrm{pH}$ increased only marginally from 8.5 to 8.7 (Fig. 4 b). In contrast, the process without external C supplementation virtually stalled after the first $12 \mathrm{~h}$ and approximately 56\% TAN was removed. The total TAN removed was $63 \%\left(1064 \mathrm{mg} \mathrm{L}^{-1}\right.$ to $\left.399 \mathrm{mg} \mathrm{L}^{-1}\right)$ by $24 \mathrm{~h}$. The dairy wastewater $\mathrm{pH}$ increased from 8.4 to 9.1 during the whole treatment time (Fig. 5b). Results also indicated $\mathrm{NH}_{3}$ lost via stripping was only $4 \%\left(44 \mathrm{mg} \mathrm{L}^{-1}\right)$ when the process was supplemented with $\mathrm{C}$ compared to $10 \%\left(109 \mathrm{mg} \mathrm{L}^{-1}\right)$ stripped when process was not supplemented with external C. These results suggest that dairy wastewater has insufficient available $\mathrm{C}$ during treatment with A. faecalis strain No. 4 and requires additional external C source to achieve $100 \%$ TAN removal. Previous studies with A. faecalis strain No. 4 with other types of wastewaters showed similar requirements (Shoda and Ishikawa, 2014; Joo et al., 2006). Joo et al. (2006), for example, observed about 100\% ammonium removal by strain No. 4 in piggery wastewater supplemented with external C source. A more recent study by Shoda and Ishikawa (2014), also reported complete ammonium removal by A. faecalis strain No. 4 in municipal wastewater supplemented with external C sources but only $20 \%$ to $30 \%$ removal rate without addition of extra $\mathrm{C}$. 


\subsubsection{Effects of Rector-Headspace Flushing with Oxygen and Air on TAN Removal}

The effect of the different oxygen sources (Oxygen and Air) for reactor headspace flushing on TAN removal from dairy wastewater with A. faecalis strain No. 4 was studied in continuous flushing batch experiments. Figure 4a depicts the changes in TAN concentration and stripped ammonia over a period of $24 \mathrm{~h}$ in batch operation experiments under continuous flush mode: (i) oxygen supply using pure oxygen gas, and (ii) oxygen supply using ambient air. The TAN removal in the batch experiment using oxygen gas was significantly higher than that in the batch experiment using air. Within the batch operation period of $24 \mathrm{~h}$, ammonium removal was almost $100 \%$ with oxygen flushing, while it was only about $42 \%$ (TAN concentration decreased from 1,100 $\mathrm{mg} \mathrm{L}^{-1}$ to $643 \mathrm{mg} \mathrm{L}^{-1}$ ) with air flushing. The dairy wastewater $\mathrm{pH}$ increased from 8.4 to 8.8 when flushing with air (Fig. $4 \mathrm{~b})$. The amount of stripped ammonia accounted for only $4 \%$ of the total TAN removal when flushing with oxygen and nearly $20 \%$ when flushing with air. The efficient TAN removal when flushing with oxygen was presumably due to the process's ability to meet the oxygen demand for A. faecalis strain No. 4 activity (Shoda and Ishikawa, 2014).

\subsubsection{Effects of Reactor-Headspace Flushing-frequency on TAN Removal}

In this study, five flushing strategies were tested: continuous and every $2,4,8$, and $24 \mathrm{~h}$, with initial average TAN concentrations ranging from 1,000-1,270 $\mathrm{mg} \mathrm{L}^{-1}$. The intermittent flushing events took approximately 5 min each to complete. The variations of the TAN removal effectiveness with flushing-frequency are shown in Fig. 6. Efficiencies of TAN removal were $99 \%, 97 \%$, and $97 \%$ within $28 \mathrm{~h}$ under continuous flushing, flushing every 2 $\mathrm{h}$, and flushing every $4 \mathrm{~h}$ flushing, respectively. However flushing with oxygen at intervals 
of $2 \mathrm{~h}$ and $4 \mathrm{~h}$ reduced the oxygen use by more than $95 \%$ compared to continuous flushing, while still achieving high TAN removal within the same period. Intermittent flushing of the reactor headspace at intervals of 2 or $4 \mathrm{~h}$, therefore, offers a more cost-effective treatment of dairy wastewater via this bioprocess. Removal effectiveness under the 8 and $24 \mathrm{~h}$ flushing frequencies were only about $51 \%$ and $46 \%$, respectively after $72 \mathrm{~h}$ treatments. Continuous flushing of reactor-headspace with oxygen resulted in almost $100 \%$ TAN removal within $24 \mathrm{~h}$ and a maximum removal rate of $59.2 \mathrm{mg} \mathrm{L}^{-1} \mathrm{~h}^{-1}$. The maximum TAN removal rates under the 2 and $4 \mathrm{~h}$ flushing frequencies were $41.9 \mathrm{mg} \mathrm{L}^{-1} \mathrm{~h}^{-1}$ and $42.8 \mathrm{mg} \mathrm{L}^{-1}$ $\mathrm{h}^{-1}$, respectively. Overall, the TAN removal rates under continuous flushing or flushing at intervals of 2 or $4 \mathrm{~h}$ were significantly higher than rates obtained in similar previous studies (Yang et al., 2015; Zhao et al., 2012; Joo et al., 2005). Treatment of high strength synthetic TAN wastewater using A. faecalis strain No. 4 in the aerated batch experiment showed a maximum TAN removal rate of $29 \mathrm{mg} \mathrm{L}^{-1} \mathrm{~h}^{-1}$ (Joo et al., 2005). Joo et al. (2006) measured a similar maximum TAN removal rate of about $29 \mathrm{mg} \mathrm{L}^{-1} \mathrm{~h}^{-1}$ in another similar study using A. faecalis strain No. 4 to treat swine wastewater supplemented with sodium citrate dehydrate as an extra C source. In another study (Zhao et al., 2012), aerated batch experiments of $A$. faecalis strain NR in basal medium with extra $\mathrm{C}$ and $\mathrm{N}$ sources yielded a maximum ammonium removal rate of $26.9 \mathrm{mg} \mathrm{L}^{-1} \mathrm{~h}^{-1}$. Another heterotrophic bacterium (Acinetobacter junii $\mathrm{YB}$ ) treating synthetic wastewater in aerated batch experiments showed maximum ammonium removal rates ranging from 8.2 to $13.7 \mathrm{mg} \mathrm{L}^{-1} \mathrm{~h}^{-1}$ (Yang et al., 2015). These results indicate that TAN removal efficiencies are dependent on oxygen concentration in the reactor-headspace and its consequent transfer into the reactor contents. Previous studies have pointed out that maintaining adequate oxygen supply in the substrate 
is critical for the enhanced activity of A. faecalis strain No. 4 and efficient ammonium removal (Shoda and Ishikawa, 2014). This study, similarly, reveals the importance of adequate oxygen supply to the bioprocess to meet oxygen demand of this heterotrophic bacterium.

\subsection{Nitrogen Mass Balance}

A mass balance of nitrogen was calculated for the continuous flushing with pure oxygen gas during the $24 \mathrm{~h}$ treatment of dairy wastewater (supplemented with external C) with A. faecalis strain No. 4 (Table 1). Figure 6 shows the changes in $\mathrm{NO}_{3}{ }^{-}$and $\mathrm{NH}_{2} \mathrm{OH}$ in flushing batch experiments. The nitrogen mass balance showed that TAN was nearly completely (99\%) removed after $24 \mathrm{~h}$. Ammoniacal nitrogen lost as $\mathrm{NH}_{3}-\mathrm{N}$ via stripping was only $4 \%$, while the majority was retained in microbial biomass (58\%). Further nitrogen balance analysis demonstrated that the remaining nitrogen portion of approximately $36 \%$ was released via denitrification as nitrogen $\left(\mathrm{N}_{2}\right)$ gas, while trace accumulations of $\mathrm{NH}_{2} \mathrm{OH}$ $(0.9 \%)$ and $\mathrm{NO}_{3}{ }^{-}(3.5 \%)$ were detected during the whole process. Hydroxylamine is recognized as a critical nitrification intermediate during the process of ammonium oxidation. Its low concentration, in the treated effluent, therefore, illustrates that most of the $\mathrm{NH}_{2} \mathrm{OH}$ was converted to $\mathrm{N}_{2}$ gas (Zhao et al., 2012; Joo et al., 2005). The mass balance values obtained in this study were in agreement with those from previous studies on treatment of other wastewaters (synthetic wastewater and piggery waste water) with $A$. faecalis strain No. 4 (Zhao et al., 2012; Joo et al., 2007, 2006, 2005). For instance, Joo et al. (2005) investigated ammonium removal characteristics of A. faecalis strain No. 4 in an aerated batch experiment using synthetic wastewaters with initial TAN ranging from 364 to 
$1,122 \mathrm{mg} \mathrm{L}^{-1}$. After $93 \mathrm{~h}$ treatment at $30^{\circ} \mathrm{C}$, almost $100 \%$ removal of TAN was achieved. Subsequent nitrogen mass balance indicated that about $50 \%$ of TAN was assimilated into the cells, and $40-50 \%$ of TAN was estimated to be lost as $\mathrm{N}_{2}$ gas. The total amount of stripped $\mathrm{NH}_{3}-\mathrm{N}$ by aeration ranged from 2-4\% of total TAN, while $\mathrm{NH}_{2} \mathrm{OH}$ and $\mathrm{NO}_{3}{ }^{-}$ contents were negligible. Zhao et al. (2012) working with a similar bacterium (A. faecalis strain NR) estimated that approximately $29 \%$ of TAN was converted to nitrogen gas, while approximately $55 \%$ ended up in the biomass due to assimilation.

\section{Conclusions}

The results obtained in this research not only exhibited, clearly, the survival capacity of A. faecalis strain No. 4 in dairy wastewater but also its ability to remove TAN efficiently. Intermittent flushing of reactor-headspace with oxygen was a more-cost effective strategy in this bio-treatment of dairy wastewater. The results, in general, revealed that adequate oxygen and $\mathrm{C}$ addition are essential in this bioprocess to promote fast and complete removal of TAN from the wastewater. Extremely low mass of TAN was lost as $\mathrm{NH}_{3}$ gas (4\%), while the majority was retained in microbial biomass (58\%) or released as nitrogen $\operatorname{gas}(36 \%)$.

\section{Acknowledgements}

The authors would like to thank Dr. Makoto Shoda, Tokyo Institute of Technology, Japan for providing the initial bacteria samples used in this research. The financial support

for this research was provided by United States Department of Agriculture via NRCS-CIG 
program (Grant \# 69-3A75-11-210) and Washington State University Agricultural Research Center (Emerging Research Issues Program).

\section{References}

1. Ahmed, T., Semmens, M.J., Voss, M.A., 2004. Oxygen transfer characteristics of hollow-fiber, composite membranes. Adv. Environ. Res. 8 (3), 637-646.

2. Beutel, M.W., Horne, A.J., 1999. A review of the effects of hypolimnetic oxygenation on lake and reservoir water quality. Lake Reserv. Manag. 15 (4), 285-297.

3. Brindle, K., Stephenson, T., Semmens, M .J., 1998. Nitrification and oxygen utilisation in a membrane aeration bioreactor. J. Membr. Sci. 144 (1), 197-209.

4. Burton, C.H., 1992. A review of the strategies in the aerobic treatment of pig slurry: purpose, theory and method. J. Agric. Eng. Res. 53, 249-272.

5. Frear, D.S., Burrell, R.C., 1955. Spectrophotometric method for determining hydroxylamine reductase activity in higher plants. Analytical Chem. 27 (10), 16641665.

6. Focht, D.D., Chang, A.C., 1975. Nitrification and denitrification processes related to waste water treatment. Adv. Appl. Microbiol. 19, 153-186. 
7. Hach Company., 2004. Chromotropic Acid Method 10020, in: DR/2400 spectrophotometer procedure manual, Loveland, USA.

8. Joo, H.S., Hirai, M., Shoda, M., 2007. Improvement in ammonium removal efficiency in wastewater treatment by mixed culture of Alcaligenes faecalis No. 4 and L1. J. Biosci. Bioeng. 103 (1), 66-73.

9. Joo, H.S., Hirai, M., Shoda, M., 2006. Piggery wastewater treatment using Alcaligenes faecalis strain No. 4 with heterotrophic nitrification and aerobic denitrification. Water Res. 40 (16), 3029-3036.

10. Joo, H.S., Hirai, M., Shoda, M., 2005. Characteristics of ammonium removal by heterotrophic nitrification-aerobic denitrification by Alcaligenes faecalis No. 4. J. Biosci. Bioeng. 100 (2), 184-191.

11. Junter, G.A., Mignot, L., Jouenne, T., 1995. Biological treatment of water using immobilized-cell systems .1. Nitrogen Removal. Chimica Oggi, 13 (10), 33-40.

12. Liao, P.H., Chen, A., Lo, K.V., 1995. Removal of nitrogen from swine manure wastewaters by ammonia stripping. Bioresour. Technol. 54 (1), 17-20.

13. Ndegwa, P.M., Wang, L., Vaddella, V.K., 2007. Stabilisation of dairy wastewater using limited-aeration treatments in batch reactors. Biosyst. Eng. 97 (3), 379-385.

14. Palmer, H., Beutel, M., Gebremariam, S., 2009. High rates of ammonia removal in experimental oxygen-activated nitrification wetland mesocosms. J. Environ. Eng. 135 (10), 972-979.

15. Speece, R. E., 1996. Oxygen supplementation by U-Tube to the Tombigbee River. Water Sci. Technol. 34 (12), 83-90. 
16. Sun, S.P., Nàcher, C.P.I., Merkey, B., Zhou, Q., Xia, S.Q., Yang, D.H., Sun, J.H., Smets, B.F., 2010. Effective biological nitrogen removal treatment processes for domestic wastewaters with low C/N ratios: a review. Environ. Eng. Sci. 27 (2), $111-$ 126.

17. Szögi, A.A., Vanotti, M.B., Rice, J.M., Humenik, F. J., Hunt, P. G., 2004. Nitrification options for pig wastewater treatment. New Zealand J. Agric. Res. 47 (4), 439-448.

18. Shoda, M., Ishikawa, Y., 2014. Heterotrophic nitrification and aerobic denitrification of high-strength ammonium in anaerobically digested sludge by Alcaligenes faecalis strain No. 4. J. Biosci. Bioeng. 117 (6), 737-741.

19. Water Pollution Federation., 1988. Aeration: Manual of Practice, FD -13.

20. Yang, L., Ren, Y.X., Liang, X., Zhao, S.Q., Xia, Z.H., 2015. Nitrogen removal characteristics of a heterotrophic nitrifier Acinetobacter junii YB and its potential application for the treatment of high-strength nitrogenous wastewater. Bioresour. Technol. 193, 227-233.

21. Zhao, B., He, Y.L., Zhang, X.F., 2010. Nitrogen removal capability through simultaneous heterotrophic nitrification and aerobic denitrification by Bacillus sp. LY. Environ. Technol. 31 (4), 409-416.

22. Zhao, B., An, Q., He, Y.L., Guo, J.S., 2012. $\mathrm{N}_{2} \mathrm{O}$ and $\mathrm{N}_{2}$ production during heterotrophic nitrification by Alcaligenes faecalis strain NR. Bioresour. Technol. 116, $379-385$.

23. Zhu, G., Peng, Y., Li, B., Guo, J., Yang, Q., Wang, S., 2008. Biological removal of nitrogen from wastewater. In Reviews of Environ. Contam. Toxicol. 192, 159-195. 


\section{List of Figure Captions}

Figure 1. The bioreactor system used to conduct batch experiments: (1) air compressor pump or oxygen-gas tank; (2) flow meter; (3) stirring hot plate for aerated experiments or shaking water bath for flushing experiments; (4) reactor; and (5) acid trap. The arrows indicate the flow direction of either air or oxygen.

Figure 2. Changes in the number of strain No. 4 cells $(\square), \mathrm{pH}(\triangle)$, concentration of TAN (O), and stripped $\mathrm{NH}_{3}-\mathrm{N}(\mathrm{O})$ in the aerated batch experiment of strain No.4 using dairy wastewater: (a) aeration using air, and (b) aeration using oxygen-gas.

Figure 3. Changes in the $\mathrm{pH}(\triangle)$, concentration of TAN $(\mathbf{O})$, and stripped $\mathrm{NH}_{3}-\mathrm{N}(\mathrm{O})$ at different air flow rates: (a) Air flow $=0.5 \mathrm{~L} \mathrm{~min}^{-1}$, and (b) Air flow $=0.2 \mathrm{~L} \mathrm{~min}^{-1}$. Each treatment was conducted using A. faecalis strain No.4 at $30^{\circ} \mathrm{C}$ and agitation rate of $115 \mathrm{rpm}$.

Figure 4. Effect of flushing reactor-headspace with air and oxygen and with and without carbon supplementation during treatment of dairy wastewater with A. faecalis strain No. 4: (a) TAN removal and ammonia stripping (circles represent oxygen and external carbon; triangles represent oxygen and without external $\mathrm{C}$ supplementation; squares represent air and external $C$ supplementation). Symbols: $\mathbf{~ / ~} \mathbf{\Delta}$, TAN concentrations; $\bigcirc / \triangle / \square$, stripped ammonia $\left.\left(\mathrm{NH}_{3}-\mathrm{N}\right)\right)$; (b) dynamics of wastewater $\mathrm{pH}$. Error bars indicate standard errors (SE) from means, $n=2$.

Figure 5. Effect of flushing-frequency on TAN removal using reactor-headspace flushing with oxygen as follows: (i) continuously (O), (ii) every 2 h ( $\boldsymbol{\square})$, (iii) every 4 h ( $\mathbf{\Delta}$ ), (iv) every $8 \mathrm{~h}(\square)$, and (v) every $24 \mathrm{~h}(\bigcirc)$. Flushing events every 2, 4, 8, and $24 \mathrm{~h}$ took $5 \mathrm{~min}$ to complete.

Figure 6. Change in concentrations of nitrate, and hydroxylamine in flushing batch experiment with oxygen. Error bars indicate standard errors (SE) from means, $n=2$. 


\section{List of Tables}

Table 1.The mean nitrogen mass balance during treatment dairy manure supplemented with external carbon sources in batch experiments using A. faecalis strain No. 4 after 24 h. ${ }^{a}$ 
Figure 1. The bioreactor system used to conduct batch experiments: (1) air compressor pump or oxygen-gas tank; (2) flow meter; (3) stirring hot plate for aerated experiments or shaking water bath for flushing experiments; (4) reactor; and (5) acid trap. The arrows indicate the flow direction of either air or oxygen.

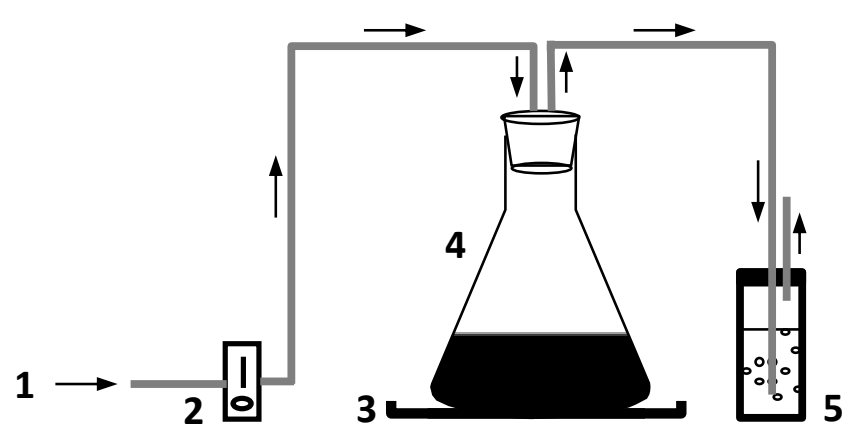


Figure 2. Changes in the number of strain No. 4 cells $(\square), \mathrm{pH}(\triangle)$, concentration of TAN $(\bullet)$, and stripped $\mathrm{NH}_{3}-\mathrm{N}(\mathrm{O})$ in the aerated batch experiment of strain No.4 using dairy wastewater: (a) aeration using air, and (b) aeration using oxygen-gas.
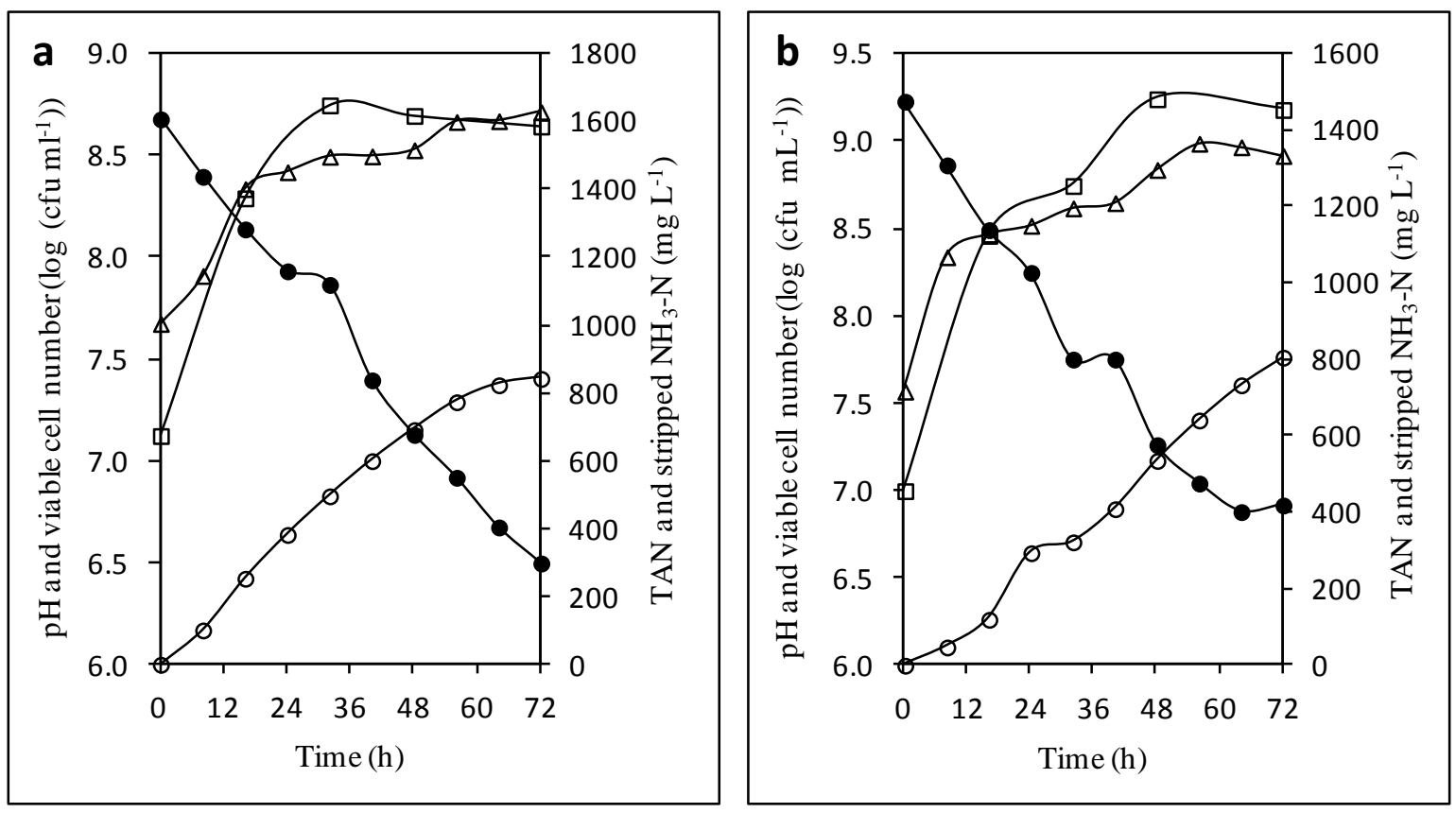
Figure 3. Changes in the $\mathrm{pH}(\triangle)$, concentration of TAN $(\bullet)$, and stripped $\mathrm{NH}_{3}-\mathrm{N}(O)$ at different air flow rates: (a) Air flow $=0.5 \mathrm{~L} \mathrm{~min}^{-1}$, and (b) Air flow $=0.2 \mathrm{~L} \mathrm{~min}^{-1}$. Each treatment was conducted using A. faecalis strain No.4 at $30^{\circ} \mathrm{C}$ and agitation rate of $115 \mathrm{rpm}$.

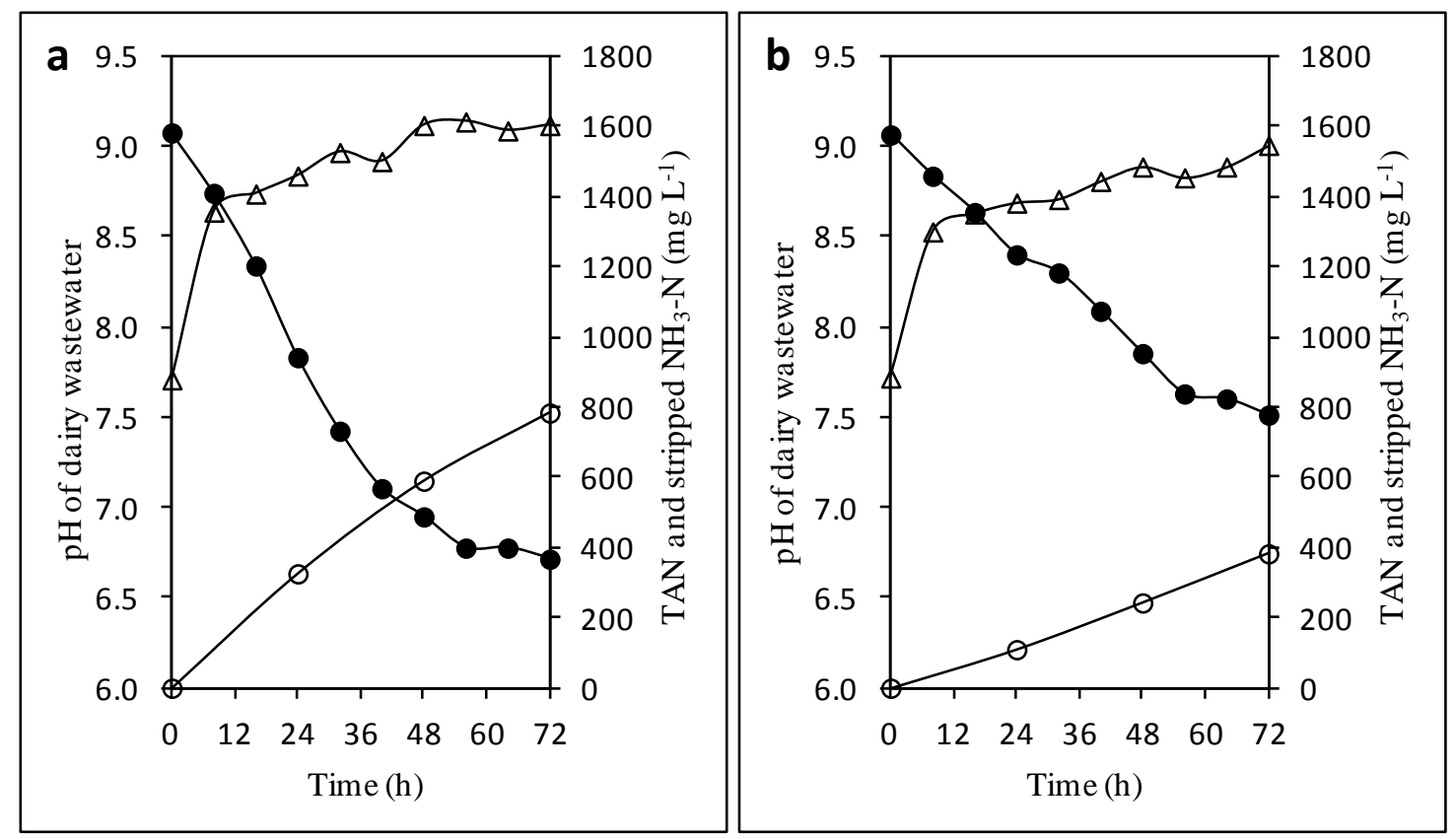


Figure 4. Effect of flushing reactor-headspace with air and oxygen and with and without carbon supplementation during treatment of dairy wastewater with A. faecalis strain No. 4: (a) TAN removal and ammonia stripping (circles represent oxygen and external carbon; triangles represent oxygen and without external $\mathrm{C}$ supplementation; squares represent air

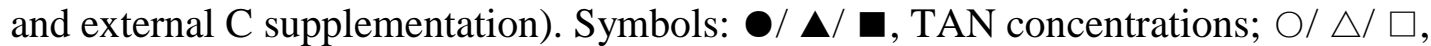
stripped ammonia $\left(\mathrm{NH}_{3}-\mathrm{N}\right)$ ); (b) dynamics of wastewater $\mathrm{pH}$. Error bars indicate standard errors (SE) from means, $n=2$.
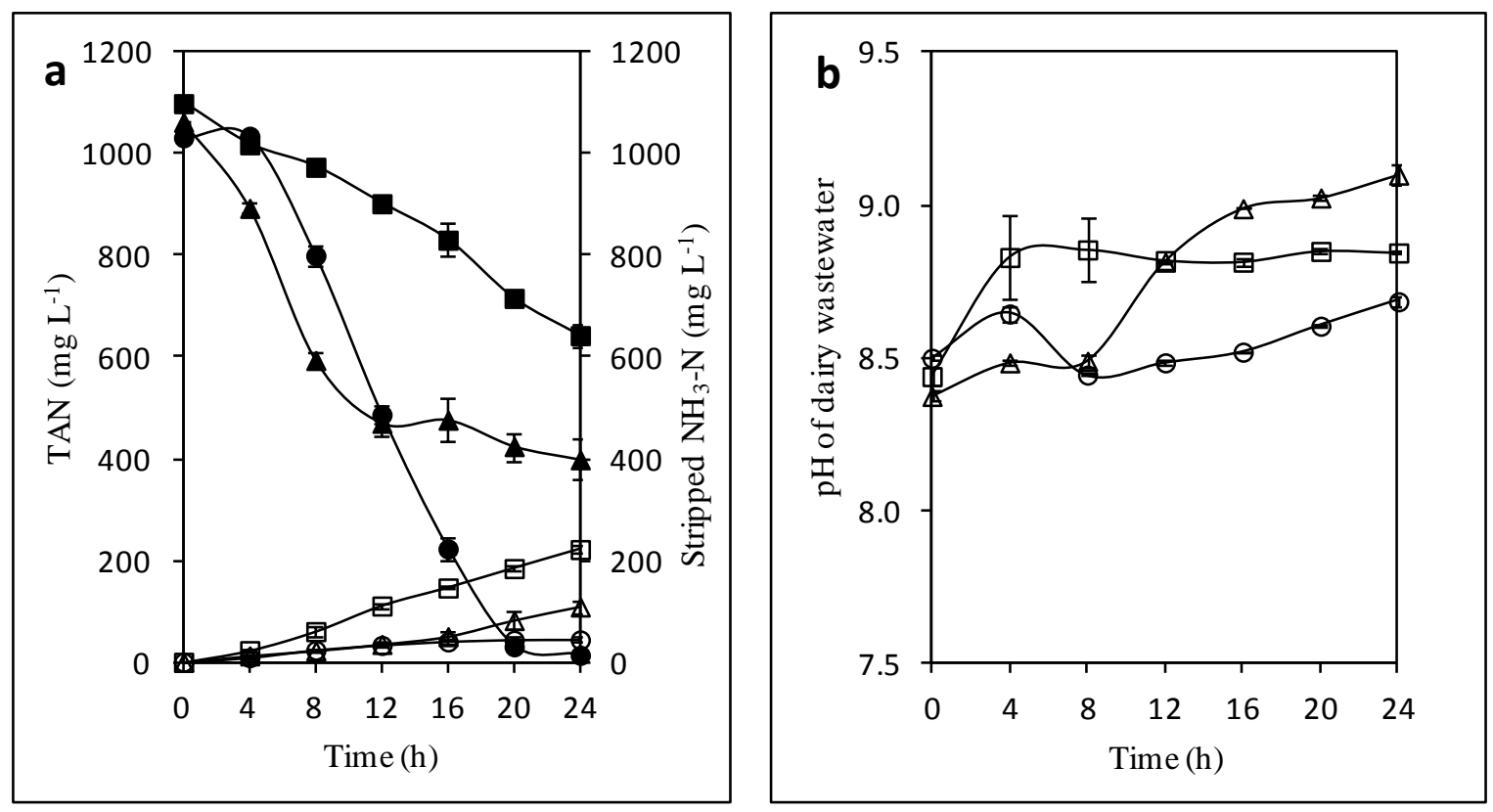
Figure 5. Effect of flushing-frequency on TAN removal using reactor-headspace flushing

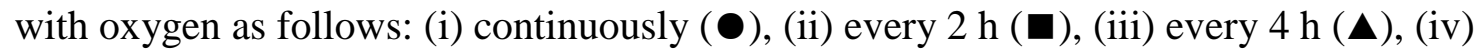
every $8 \mathrm{~h}(\square)$, and (v) every $24 \mathrm{~h}(\bigcirc)$. Flushing events every 2, 4, 8, and $24 \mathrm{~h}$ took $5 \mathrm{~min}$ to complete.

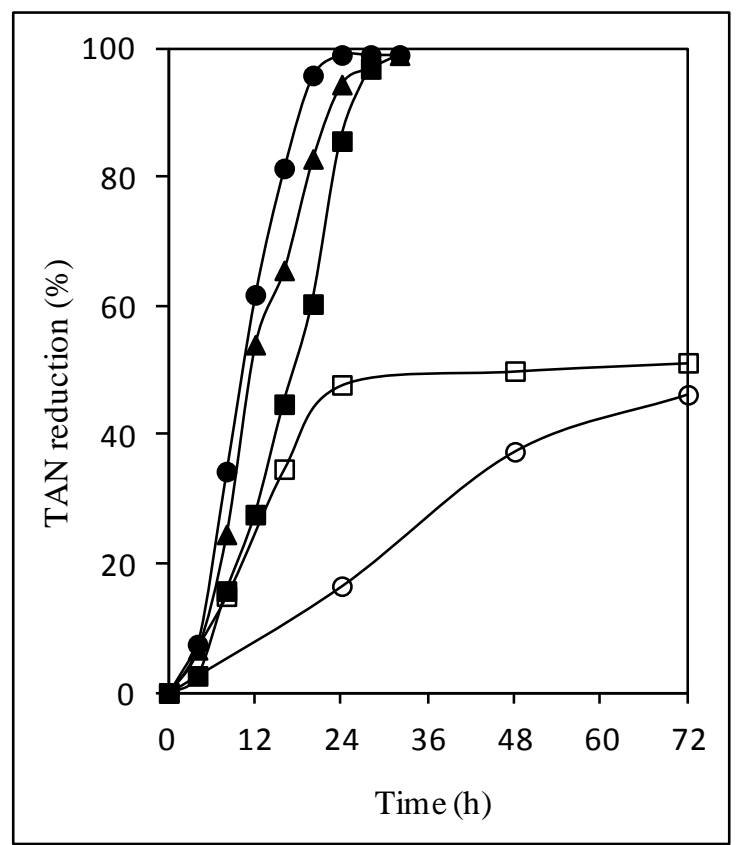


Figure 6. Change in concentrations of nitrate, and hydroxylamine in flushing batch experiment with oxygen. Error bars indicate standard errors (SE) from means, $n=2$.

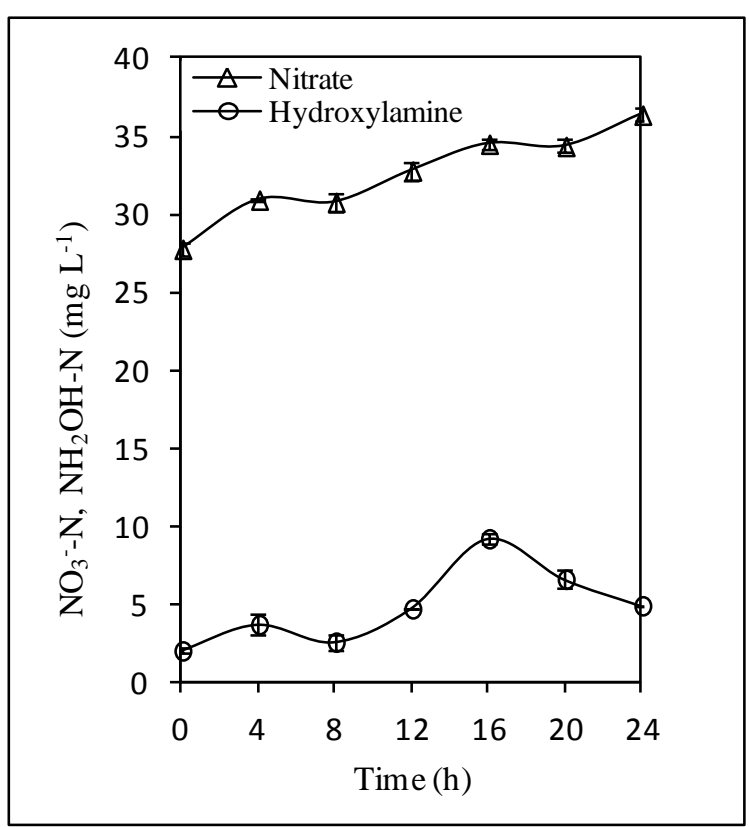


Table 1.The mean nitrogen mass balance during treatment dairy manure supplemented with external carbon sources in batch experiments using A. faecalis strain No. 4 after 24 h. ${ }^{\text {a }}$

\begin{tabular}{llllll}
\hline $\begin{array}{l}\text { Initial } \\
\text { TAN }\end{array}$ & $\begin{array}{l}\text { Final } \\
\text { TAN }\end{array}$ & $\begin{array}{l}\text { Removed } \\
\text { TAN }(\%)\end{array}$ & $\begin{array}{l}\text { Stripped } \\
\mathrm{NH}_{3}(\%)\end{array}$ & $\begin{array}{l}\text { Assimilated } \\
\text { TAN }(\%)\end{array}$ & $\begin{array}{l}\text { Denitrified } \\
\text { TAN (\%) }\end{array}$ \\
\hline 1033 & 14 & $1019(99)^{\mathrm{b}}$ & $44(4)$ & $600(58)$ & $375(36)$ \\
\hline
\end{tabular}

${ }^{\text {a }}$ Experiment was conducted at $30^{\circ} \mathrm{C}$ at a speed of $100 \mathrm{rpm}$ in a shaking flask under continuous

flushing of reactor-headspace with oxygen-gas. The test sample consisted of the dairy wastewater with strain No. 4, and trisodium citrate dehydrate (as external carbon source).

${ }^{\mathrm{b}}$ Mean of two replicates, $\mathrm{mg} \mathrm{L}^{-1}$ (percentage in parenthesis). 